\title{
Cover features and new Associate Editors of the Journal of Environmental Sciences
}

\author{
Qingcai Feng ${ }^{1}$, Suqin $\mathrm{Li}^{1}$, Zhengang $\mathrm{Mao}^{1}$, Jian Xu $\mathrm{Xu}^{1}$, Zixuan Wang ${ }^{1}, \mathrm{X}$. Chris $\mathrm{Le}^{2}$,* \\ 1. Research Center for Eco-Environmental Sciences, Chinese Academy of Sciences, Beijing 100085, China \\ 2. Division of Analytical and Environmental Toxicology, Department of Laboratory Medicine and Pathology, University of Alberta, Edmonton, \\ Alberta T6G 2G3, Canada
}

We are very pleased to announce that five Associate Editors have joined the editorial team of the Journal of Environmental Sciences (JES). Professors/Drs. Yong Cai, Paul Lam, Jonathan Martin, Michael Plewa, and Po Keung Wong bring a wealth of expertise in environmental sciences. As preeminent scientists in their chosen areas of research, they have made outstanding contributions to the discipline of environmental sciences. Their tremendous expertise and dedication to JES will contribute to the continuing success of the journal in achieving high-quality scientific communication of environmental research. Their close collaboration with environmental science researchers, authors, reviewers, and the editorial team of advisors, editors, and editorial board members will further strengthen JES.

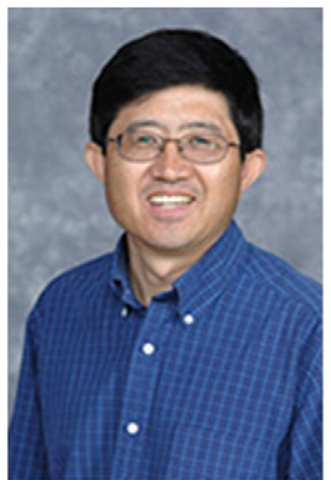

Dr. Yong Cai is a Professor and Chair in the Department of Chemistry and Biochemistry and the Southeast Environmental Research Center (SERC) at Florida International University (FIU). He directs the Environmental Bioinorganic Chemistry Research Group within FIU. He conducts research in the broad field of chemistry and environmental science, focusing on speciation analysis of toxic metals and metalloids in the environment and biological systems, studies of their fate and transport, and assessment of their environmental and public health impact. In particular, the research programme in his laboratory addresses many interrelated molecular-level questions regarding the environmental fate and health effect of mercury (Yin et al., 2014; Wang et al.,
2016) and arsenic (Li and Cai, 2015; Liu et al., 2011). He has published two books (Cai and Braids, 2002; Liu et al., 2012) and more than 120 papers in peer-reviewed journals and over 10 contributed chapters in major professional monographs, and delivered numerous conference presentations. Serving as an Associate Editor of JES, Dr. Cai recently highlighted the work on toxic metals in sediment (Li and Cai, 2015) and mercury emission to the atmosphere (Wang et al., 2016).

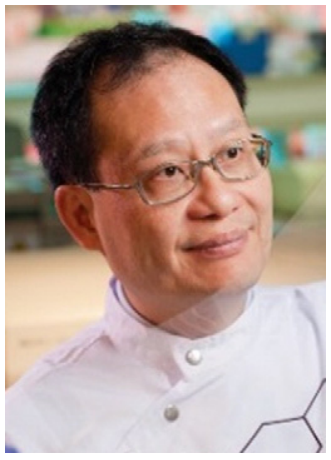

Dr. Paul K.S. Lam is the Chief-of-Staff (Vice-President) and Chair Professor of Biology at the City University of Hong Kong, with research interests in the areas of ecology, eco-toxicology, environmental toxicology, and risk assessment (Cheung et al., 2001; Lam et al., 2009; Lin et al., 2015; Loi et al., 2011; Lyu et al., 2015; So et al., 2004). He is also the Director of the State Key Laboratory in Marine Pollution. He was an Associate Editor of the "Environmental Toxicology and Risk Assessment" section of Chemosphere (2004-2008). He is a member of the Editorial Advisory Board of Environmental Science and Technology (since 2010). Professor Lam actively participates in community service. He is currently the Chairman of the Advisory Council on the Environment. He was appointed as a Justice of the Peace by the Hong Kong SAR Government in 2008. He was awarded the Silver Bauhinia Star (SBS) in 2014. Dr. Lam and Dr. Leo Yeung of Örebro University (Sweden) are jointly editing a special issue on the topic of "emerging chemical contaminants of concern", scheduled for publication in 2017 in JES.

\footnotetext{
* Corresponding author.

E-mail address: xc.le@ualberta.ca (X.C. Le).
} 


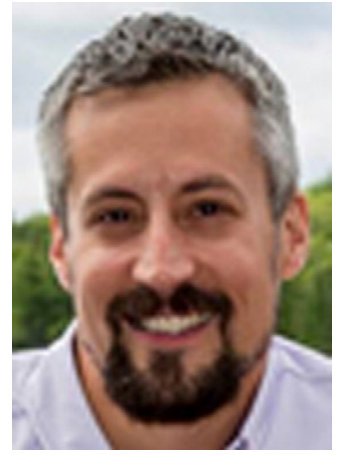

Dr. Jonathan W. Martin is a Professor of Analytical Environmental Chemistry and Toxicology. His ongoing research at the University of Alberta, Canada, includes untargeted methods for contaminant discovery (Liu et al., 2015a; Martin and Pereira, 2015), studies of exposure sources and pathways (Zhang et al., 2016), investigations of pharmacokinetics and transformation for emerging contaminants (Beesoon and Martin, 2015), and the effects of early-life chemical exposures on human development and health (Webster et al., 2014; Ye et al., 2016). The results of these studies have been highly cited (H-index 48) and have influenced chemical regulatory decisions in Canada and on the international stage. He is an elected member of the Royal Society of Canada's College of New Scholars, Artists and Scientists and was recently named as one of the most Influential Scientific Minds by Thomson Reuters (2014). He has served on journal editorial boards for Environmental Toxicology and Chemistry and Science of the Total Environment and has been acknowledged for his 'Excellence in Review' by Environmental Science \& Technology.

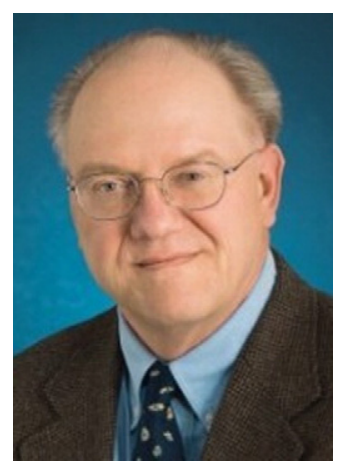

Dr. Michael J. Plewa is an Emeritus Professor of Genetics and University Scholar at the University of Illinois at Urbana-Champaign in the College of Agricultural, Consumer and Environmental Sciences and the Associate Director of the Safe Global Water Institute in the College of Engineering. Working with colleagues to integrate analytical biology with analytical chemistry, he developed the largest database on the in vitro toxicology of water disinfection by-products (DBPs). His research interest involves identifying the molecular mechanisms of DBP toxicity and defining the forcing factors that lead to toxicity in disinfected water (Pals et al., 2013; Plewa et al., 2010; Plewa et al., 2004; Plewa and Wagner, 2009, 2015; Wagner et al., 2012). Dr. Plewa has over 230 publications in environmental and molecular mutagenesis and genetic toxicology. He is a past president of the Environmental Mutagenesis and Genomics Society and was the Chair of the 2015 Gordon Research Conference on DBPs. Dr. Plewa is currently organizing and editing a special issue on "water treatment and disinfection by-products". This special issue will be published in JES before the 2017 Gordon Research Conference on DBPs (https://www. grc.org/programs.aspx?id=14983).

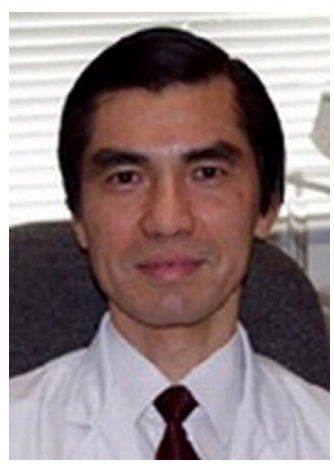

Dr. Po Keung (P.K.) Wong has more than 35 years working experience on environmental technology/biotechnology and photocatalysis. He received his Ph.D. degree in Microbiology from the University of California at Davis (UCD) in 1983. Currently, he is a Professor in the School of Life Sciences and the Associate Director of the Environmental Science Programme, Chinese University of Hong Kong (CUHK). He also serves as a visiting professor for Nankai University, South China University of Technology, Central China Normal University, Guangdong University of Technology, and Guangzhou Institute of Geochemistry, Chinese Academy of Sciences, China, and an adjunct professor for Clemson University, USA. He is an Associate Editor of JES and a Coordinating Editor of Environmental Geochemistry and Health. Professor Wong has recently (2015) received a Higher Education Outstanding Scientific Research Output Award (Science and Technology) in the category of Natural Sciences (Second Class) of Ministry of Education, China, for his contribution to the field of photocatalytic treatment of drinking water and wastewater. He has published more than 200 articles on various aspects of environmental technology/biotechnology and photocatalysis (Li et al., 2009, 2011; Ng et al., 2016; Xia et al., 2016; Xiang et al., 2011; Wang et al., 2015; Zhang et al., $2009,2010)$. According to the Essential Science indicators, many of his papers are "highly cited" (Li et al., 2009; Xiang et al., 2011; Zhang et al., 2009, 2010). His recent work on the development of photocatalysts and mechanistic studies of photocatalytic disinfection of bacteria (Wang et al., 2015) has been featured on a cover of JES.

Professional journal covers can attract readers' attention and generate further interest. The cover of each print issue of JES features a particular topic or a paper published in that issue. JES publishes twelve issues a year on a monthly basis, although the accepted and edited manuscripts are published online, usually several months ahead of the monthly print issues. Typically 25-30 papers are published in each issue, for a total yearly publication of approximately 300 papers. These papers are selected from about 3000 manuscripts submitted to JES each year. The eventual publication of the small fraction of the submitted manuscripts is a result of vigorous peer reviews and necessary revisions that involve collaborative efforts of authors, reviewers, editors, and publisher(s).

Several covers of JES have featured research on arsenic (Zan et al., 2014; Hao et al., 2015) and mercury (Cheng et al., 2015), because of their environmental significance. Arsenic consistently ranks on top of the priority list of toxic substances, according to the Agency for Toxic Substances and Diseases Registry (ATSDR). More than 900 Superfund sites in the United States list arsenic contamination as a concern. More than 100 million people around the world are at risk of exposure to arsenic at levels exceeding the World Health Organization guidelines (Nordstrom, 2002; WHO, 2011). Appropriately, JES has featured new analytical methods for the detection of arsenic (Hao et al., 2015), studies on its environmental fate and behaviour (Zan et al., 2014; Zhang et al., 2014), 
minimizing potential human exposure (Newbigging et al., 2015), and removal technologies (Du et al., 2014).

In addition to the environmental contaminants that have been known and studied extensively for many years, emerging contaminants such as perfluorinated compounds (Beesoon and Martin, 2015; Liu et al., 2015b), nanomaterials (Yin et al., 2015; Popowich et al., 2015), and DBPs (Richardson and Kimura, 2016; Zeng et al., 2016), have received much attention. For example, recycling of electronic waste (Li et al., 2014; Tang et al., 2015; Peng et al., 2015) can result in the release and environmental contamination of heavy metals as well as emerging persistent organic contaminants, such as polybrominated compounds.

Much recent research deals with a group of emerging contaminants that are byproducts formed during the water disinfection process (Richardson and Kimura, 2016; Zeng et al., 2016). Water disinfection is the most effective public health measure to prevent waterborne infectious disease. Multiple barrier removal strategies are usually implemented to reduce microbial risk (Zhang et al., 2015a, 2015b). In addition, disinfection processes are necessary for drinking water. While water disinfection reduces microbial risk, the DBPs formed between the disinfectants and the natural organic matter in water are undesirable. Recent research on the water disinfection (Mi et al., 2015; Ng et al., 2015) and the formation of DBPs (Zhang et al., 2015b) has been highlighted.

Research involving all environmental media, including air quality and haze/smog formation (Han et al., 2015; L. Zhou et al., 2014; Lee, 2015), release of greenhouse gas (Chen et al., 2014), water quality and nutrients (Sharpley and Wang, 2014; Ye et al., 2014; Gao et al., 2015), and soil and remediation (Qi et al., 2014), has been featured on the covers of JES. As an inclusive environmental research publication, JES showcases all aspects of environmental sciences, ranging from molecular-level studies of environmental contaminants and their potential health risks (Lee et al., 2015; Zhou, 2015), to monitoring and treatment technologies (Gao et al., 2015; Cui and Luan, 2015), and to the global issues of energy and climate (Y. Zhou et al., 2014; Yu et al., 2015).

With the support of environmental science researchers, authors and readers, reviewers, and the editorial team, JES strives to best serve the environmental science community by communicating pertinent research findings of significant impact.

\section{R E F E R E N C E S}

Beesoon, S., Martin, J.W., 2015. Isomer-specific binding affinity of perfluorooctanesulfonate (PFOS) and perfluorooctanoate (PFOA) to serum proteins. Environ. Sci. Technol. 49, 5722-5731.

Cai, Y., Braids, O. (Eds.), 2002. Biogeochemistry of Environmentally Important ElementsACS Symposium
Series 835. Oxford University Press, American Chemical Society, Washington, DC.

Chen, Q.Q., Zhu, R.B., Wang, Q., Xu, H., 2014. Methane and nitrous oxide fluxes from four tundra ecotopes in Ny-Ålesund of the High Arctic. J. Environ. Sci. 26 (7), 1403-1410.

Cheng, J.P., Fujimura, M., Bo, D.D., 2015. Assessing pre/post-weaning neurobehavioral development for perinatal exposure to low doses of methylmercury. J. Environ. Sci. 38, 36-41.

Cheung, C.C.C., Zheng, G.J., Li, A.M.Y., Richardson, B.J., Lam, P.K.S., 2001. Relationships between tissue concentrations of polycyclic aromatic hydrocarbons and antioxidative responses of marine mussels, Perna viridis. Aquat. Toxicol. 52, 189-203.

Cui, Y.B., Luan, J.F., 2015. Synthesis, crystal structure, photodegradation kinetics and photocatalytic activity of novel photocatalyst $\mathrm{ZnBiYO}_{4}$. J. Environ. Sci. 29, 51-61.

Du, J.J., Jing, C.Y., Duan, J.M., Zhang, Y.L., Hu, S., 2014. Removal of arsenate with hydrous ferric oxide coprecipitation: effect of humic acid. J. Environ. Sci. 26 (2), 240-247.

Gao, J.F., O’Brien, J., Lai, F.Y., van Nuijs, A.L.N., He, J., Mueller, J.F., et al., 2015. Could wastewater analysis be a useful tool for China? - a review. J. Environ. Sci. 27, 70-79.

Han, T.T., Liu, X.G., Zhang, Y.H., Qu, Y., Zeng, L.M., Hu, M., et al., 2015. Role of secondary aerosols in haze formation in summer in the Megacity Beijing. J. Environ. Sci. 31, 51-60.

Hao, J.M., Han, M.J., Han, S.M., Meng, X.G., Su, T.L., Wang, Q.W.K., 2015. SERS detection of arsenic in water: a review. J. Environ. Sci. 36, 152-162.

Lam, J.C.W., Lau, R.K.F., Murphy, M.B., Lam, P.K.S., 2009. Temporal trends of hexabromocyclododecanes (HBCDs) and polybrominated diphenyl ethers (PBDEs) and detection of two novel flame retardants in marine mammals from Hong Kong, South China. Environ. Sci. Technol. 43, 6944-6949.

Lee, A.K.Y., 2015. Haze formation in China: importance of secondary aerosol. J. Environ. Sci. 33, 261-262.

Lee, J.W., Won, E.J., Raisuddin, S., Lee, J.S., 2015. Significance of adverse outcome pathways in biomarker-based environmental risk assessment in aquatic organisms. J. Environ. Sci. 35, 115-127.

Li, Y., Cai, Y., 2015. Mobility of toxic metals in sediments: assessing methods and controlling factors. J. Environ. Sci. 31, 203-205.

Li, G.T., Wong, K.H., Zhang, X.W., Hu, C., Yu, J.C., Chan, C.Y., Wong, P.K., 2009. Degradation of Acid Orange 7 using magnetic AgBr under visible light: the roles of oxidizing species. Chemosphere 76, 1185-1191.

Li, G.T., Yip, H.Y., Wong, K.H., Hu, C., Qu, J.H., Wong, P.K., 2011. Photoelectrochemical degradation of methylene blue with $\beta-\mathrm{PbO}_{2}$ electrode driven by visible light irradiation. J. Environ. Sci. 23, 988-1033.

Li, L., Wang, W.Y., Lv, Q.X., Ben, Y.J., Li, X.H., 2014. Bioavailability and tissue distribution of Dechloranes in wild frogs (Rana limnocharis) from an e-waste recycling area in Southeast China. J. Environ. Sci. 26 (3), 636-642.

Lin, B.K., Lyu, J.L., Lyu, X.J., Yu, H.Q., Hu, Z., Lam, J.C.W., Lam, P.K.S., 2015. Characterization of cefalexin degradation capabilities of two Pseudomonas strains isolated from activated sludge. J. Hazard. Mater. 282, 158-164.

Liu, G., Fernandez, A., Cai, Y., 2011. Complexation of arsenite with humic acid in the presence of ferric iron. Environ. Sci. Technol. 45, 3210-3216.

Liu, G.L., Cai, Y., O’Driscoll, N. (Eds.), 2012. Advances in Environmental Chemistry and Toxicology of Mercury. John \& Wiley Book.

Liu, Y., Pereira, A.S., Martin, J.W., 2015a. Discovery of poly- and perfluoroalkyl substances in water by in-line SPE-HPLC-Orbitrap with in-source fragmentation flagging. Anal. Chem. 87, 4260-4268.

Liu, H., Sheng, N., Zhang, W., Dai, J., 2015b. Toxic effects of perfluorononanoic acid on the development of Zebrafish (Danio rerio) embryos. J. Environ. Sci. 32, 26-34.

Loi, E.I.H., Yeung, L.W.Y., Taniyasu, S., Lam, P.K.S., Kannan, K., Yamashita, N., 2011. Trophic biomagnification of poly- and 
per-fluorinated compounds in a subtropical food web. Environ. Sci. Technol. 45, 5506-5513.

Lyu, X.J., Li, W.W., Lam, P.K.S., Yu, H.Q., 2015. Insights into perfluorooctane sulfonate photodegradation in a catalyst-free aqueous solution. Sci. Rep. 5, 9353.

Martin, J.W., Pereira, A.S., 2015. Exploring the complexity of oil sands process-affected water by high efficiency supercritical fluid chromatography/orbitrap mass spectrometry. Rapid Commun. Mass Spectrom. 29, 735-744.

Mi, Z.L., Dai, Y., Xie, S.G., Chen, C., Zhang, X.J., 2015. Impact of disinfection on drinking water biofilm bacterial community. J. Environ. Sci. 37, 200-205.

Newbigging, A.M., Paliwoda, R.E., Le, X.C., 2015. Rice: reducing arsenic content by controlling water irrigation. J. Environ. Sci. 30, 129-131.

Ng, T.W., Huang, G.C., Wong, P.K., 2015. Investigation of drinking water bacterial community through high-throughput sequencing. J. Environ. Sci. 37, 154-156.

Ng, T.W., Zhang, L.S., Liu, J.S., Huang, G.C., Wang, W., Wong, P.K., 2016. Visible-light-driven photocatalytic inactivation of Escherichia coli by magnetic $\mathrm{Fe}_{2} \mathrm{O}_{3}-\mathrm{AgBr}$. Water Res. 90, 111-118.

Nordstrom, D.K., 2002. Public health - worldwide occurrences of arsenic in ground water. Science 296, 2143-2145.

Pals, J., Attene-Ramos, M.S., Xia, M., Wagner, E.D., Plewa, M.J., 2013. Human cell toxicogenomic analysis linking reactive oxygen species to the toxicity of monohaloacetic acid drinking water disinfection byproducts. Environ. Sci. Technol. 47, 12,514-12,523.

Peng, H., Reid, M.S., Le, X.C., 2015. Consumption of rice and fish in an electronic waste recycling area contributes significantly to total daily intake of mercury. J. Environ. Sci. 38, 83-86. http://dx. doi.org/10.1016/j.jes.2015.10.003.

Plewa, M.J., Wagner, E.D., 2009. Mammalian Cell Cytotoxicity and Genotoxicity of Disinfection By-Products. Water Research Foundation, Denver, CO, p. 134 (ISBN-978-1-60573-052-3).

Plewa, M.J., Wagner, E.D., 2015. Charting a new path to resolve the adverse health effects of DBPs. In: Karanfil, T., Mitch, W., Westerhoff, P., Xie, Y. (Eds.), Occurrence, Formation, Health Effects, and Control of Disinfection By-Products vol. 1190. American Chemical Society, Washington, D.C., pp. 3-23.

Plewa, M.J., Wagner, E.D., Richardson, S.D., Thruston Jr., A.D., Woo, Y.T., McKague, A.B., 2004. Chemical and biological characterization of newly discovered iodoacid drinking water disinfection byproducts. Environ. Sci. Technol. 38, 4713-4722.

Plewa, M.J., Simmons, J.E., Richardson, S.D., Wagner, E.D., 2010. Mammalian cell cytotoxicity and genotoxicity of the haloacetic acids, a major class of drinking water disinfection by-products. Environ. Mol. Mutagen. 51 (8-9), 871-878.

Popowich, A., Zhang, Q., Le, X.C., 2015. Removal of nanoparticles by coagulation. J. Environ. Sci. 38, 168-171.

Qi, Y.C., Liu, X.C., Dong, Y.S., Peng, Q., He, Y.T., Sun, L.J., et al., 2014. Differential responses of short-term soil respiration dynamics to the experimental addition of nitrogen and water in the temperate semi-arid steppe of Inner Mongolia, China. J. Environ. Sci. 26 (4), 834-845.

Richardson, S.D., Kimura, S.Y., 2016. Water analysis: emerging contaminants and current issues. Anal. Chem. 88, 546-582.

Sharpley, A., Wang, X.Y., 2014. Managing agricultural phosphorus for water quality: lessons from the USA and China. J. Environ. Sci. 26 (9), 1770-1782.

So, M.K., Taniyasu, S., Yamashita, N., Giesy, J.P., Zheng, J., Fang, Z., Im, S.H., Lam, P.K.S., 2004. Perfluorinated compounds in coastal waters of Hong Kong, South China and Korea. Environ. Sci. Technol. 38, 4056-4063.

Tang, W., Cheng, J.P., Zhao, W.C., Wang, W.H., 2015. Mercury levels and estimated total daily intakes for children and adults from an electronic waste recycling area in Taizhou, China: key role of rice and fish consumption. J. Environ. Sci. 34, 107-115.

Wagner, E.D., Hsu, K.M., Lagunas, A., Mitch, W.A., Plewa, M.J., 2012. Comparative genotoxicity of nitrosamine drinking water disinfection byproducts in Salmonella and mammalian cells. Mutat. Res. Genet. Toxicol. Environ. Mutagen. 741 (1-2), 109-115.

Wang, W.J., Huang, G.C., Yu, J.C., Wong, P.K., 2015. Advances in photocatalytic disinfection of bacteria: development of photocatalysts and mechanisms. J. Environ. Sci. 34, 232-247.

Wang, Y., Liu, G.L., Wang, D.Y., Cai, Y., 2016. Refining mercury emission estimations to the atmosphere from iron and steel production. J. Environ. Sci. 43, 1-3.

Webster, G.M., Venners, S.A., Mattman, A., Martin, J.W., 2014. Associations between perfluoroalkyl acids (PFASs) and maternal thyroid hormones in early pregnancy: a population-based cohort study. Environ. Res. 133, 338-347.

WHO, 2011. Guidelines for Drinking-Water Quality. Fourth edition. World Health Organization, Geneva, Switzerland. Available: http://www.who.int/water_sanitation_health/dwq/guidelines/ en/ (Accessed September 4, 2016).

Xia, D.H., An, T.C., Li, G.Y., Wang, W.J., Zhao, H.J., Wong, P.K., 2016. Synergistic photocatalytic inactivation mechanisms of bacteria by graphene sheets grafted plasmonic Ag single bond AgX $(\mathrm{X}=\mathrm{Cl}, \mathrm{Br}, \mathrm{I})$ composite photocatalyst under visible light irradiation. Water Res. 99, 149-161.

Xiang, Q.J., Yu, J.G., Wong, P.K., 2011. Quantitative characterization of hydroxyl radicals produced by various photocatalysts. J. Colloid Interface Sci. 357, 163-167.

Ye, Z.L., Shen, Y., Ye, X., Zhang, Z.J., Chen, S.H., Shi, J.W., 2014. Phosphorus recovery from wastewater by struvite crystallization: property of aggregates. J. Environ. Sci. 26 (5), 991-1000.

Ye, M., Beach, J., Martin, J.W., Senthilselvan, A., 2016. Urinary concentrations of pyrethroid metabolites and its association with lung function in a Canadian general population. Occup. Environ. Med. 73, 119-126.

Yin, Y., Li, Y.B., Tai, C., Cai, Y., Jiang, G.B., 2014. Methyl iodide, a recently registered fumigant, can methylate inorganic mercury species to toxic methyl mercury in natural waters. Nat. Commun. 5, 4633.

Yin, Y.G., Yang, X.Y., Zhou, X.X., Wang, W.D., Yu, S.J., Liu, J.F., et al., 2015. Water chemistry controlled aggregation and photo-transformation of silver nanoparticles in environmental waters. J. Environ. Sci. 34, 116-125.

Yu, B., Li, X., Qiao, Y.B., Shi, L., 2015. Low-carbon transition of iron and steel industry in China: carbon intensity, economic growth and policy intervention. J. Environ. Sci. 28, 137-147.

Zan, F.Y., Huo, S.L., Zhang, J.T., Zhang, L., Xi, B.D., Zhang, L.Y., 2014. Arsenic fractionation and contamination assessment in sediments of thirteen lakes from the East Plain and Yungui Plateau Ecoregions, China. J. Environ. Sci. 26 (10), 1977-1984.

Zeng, T., Plewa, M.J., Mitch, W.A., 2016. N-nitrosamines and halogenated disinfection byproducts in U.S. Full Advanced Treatment trains for potable reuse. Water Res. 101, 176-186.

Zhang, L.S., Wong, K.H., Chen, Z.G., Yu, J.C., Zhao, J.C., Hu, C., Chan, C.Y., Wong, P.K., 2009. AgBr-Ag- $\mathrm{Bi}_{2} \mathrm{WO}_{6}$ nanojunction system: a novel and efficient photocatalyst with double visible-light active components. Appl. Catal. A Gen. 363, 221-229.

Zhang, L.S., Wong, K.H., Yip, H., Yin, H.C., Yu, J.C., Chan, C.Y., Wong, P.K., 2010. Effective photocatalytic disinfection of E. coli $\mathrm{K}-12$ using $\mathrm{AgBr}-\mathrm{Ag}-\mathrm{Bi}_{2} \mathrm{WO}_{6}$ nanojunction system irradiated by visible light: the role of diffusing hydroxyl radicals. Environ. Sci. Technol. 44, 1392-1398. 
Zhang, L.K., Yang, H., Tang, J.S., Qin, X.Q., Yu, A.Y., 2014. Attenuation of arsenic in a karst subterranean stream and correlation with geochemical factors: a case study at Lihu, South China. J. Environ. Sci. 26 (11), 2222-2230.

Zhang, Y., Chen, Z.M., An, W., Xiao, S.M., Yuan, H.Y., Zhang, D.Q., et al., 2015a. Risk assessment of Giardia from a full scale MBR sewage treatment plant caused by membrane integrity failure. J. Environ. Sci. 30, 252-258.

Zhang, H.T., Dong, H.Y., Adams, C., Qiang, Z.M., Luan, G., Wang, L., 2015b. Formation and speciation of disinfection byproducts during chlor(am)ination of aquarium seawater. J. Environ. Sci. 33, 116-124.

Zhang, Y., Shotyk, W., Zaccone, C., Noernberg, T., Pelletier, R., Bicalho, B., Froese, D., Davies, L.J., Martin, J.W., 2016. Airborne petcoke dust is a major source of polycyclic aromatic hydrocarbons in the Athabasca oil sands region. Environ. Sci. Technol. 50, 1711-1720.

Zhou, B.S., 2015. Adverse outcome pathway: framework, application, and challenges in chemical risk assessment. J. Environ. Sci. 35, 191-193.

Zhou, L., Wang, W.G., Gai, Y.B., Ge, M.F., 2014. Knudsen cell and smog chamber study of the heterogeneous uptake of sulfur dioxide on Chinese mineral dust. J. Environ. Sci. 26 (12), 2423-2433.

Zhou, Y., Hao, F.H., Meng, W., Fu, J.F., 2014. Scenario analysis of energy-based low-carbon development in China. J. Environ. Sci. 26 (8), 1631-1640. 